Article

\title{
Perceived Social Support for a Sustainable Adolescence: A Theoretical Model of Its Sources and Types
}

\author{
Arantzazu Rodríguez-Fernández ${ }^{1, * \mathbb{D}}$, Iker Izar-de-la-Fuente ${ }^{1} \mathbb{D}$, Naiara Escalante ${ }^{1}$ a and Lorea Azpiazu $^{2} \mathbb{D}$ \\ 1 Department of Developmental and Educational Psychology, Education and Sports Faculty of Vitoria-Gasteiz, \\ University of the Basque Country (UPV/EHU), Juan Ibañez de Sto. Domingo 1 Street, \\ 01006 Vitoria-Gasteiz, Spain; iker.izardelafuente@ehu.eus (I.I.-d.-l.-F.); naiara.escalante@ehu.eus (N.E.) \\ 2 Department of Developmental and Educational Psychology, Faculty of Education, \\ Philosophy and Anthropology, University of the Basque Country (UPV/EHU), Tolosa Avenue 70 Street, \\ 20018 San Sebastian, Spain; lorea.azpiazu@ehu.eus \\ * Correspondence: arantzazu.rodriguez@ehu.eus
}

Citation: Rodríguez-Fernández, A.; Izar-de-la-Fuente, I.; Escalante, N.; Azpiazu, L. Perceived Social Support for a Sustainable Adolescence: A Theoretical Model of Its Sources and Types. Sustainability 2021, 13, 5657. https://doi.org/10.3390/su13105657

Academic Editor: Ans Vercammen

Received: 25 March 2021

Accepted: 14 May 2021

Published: 18 May 2021

Publisher's Note: MDPI stays neutral with regard to jurisdictional claims in published maps and institutional affiliations.

Copyright: (c) 2021 by the authors. Licensee MDPI, Basel, Switzerland. This article is an open access article distributed under the terms and conditions of the Creative Commons Attribution (CC BY) license (https:// creativecommons.org/licenses/by/ $4.0 /)$

\begin{abstract}
Despite the growing interest in perceived social support as a means of achieving sustainable psychological development and well-being in the various contexts of the adolescent, its definition and composition remain unclear. The aim of this study is to test both the hierarchical order and the types and sources of a theoretical model of the social support perceived by adolescents. The model is based on the theories of Tardy and Lin, as well as on the findings of recent studies on the construct. Three theoretical models are compared using the structural equations method. The participants were 1081 randomly selected secondary school students (aged 12-18 years) from the north of Spain, who completed the APIK Perceived Social Support Questionnaire. The model positing that perceived social support comprises a hierarchical first level formed by sources of support (family, friends and teachers) and a lower second level derived from the first one, formed by types of support (emotional, material and informational), proved to be the first-choice solution. The results establish a solid theoretical base for both future studies on perceived social support during adolescence and possible educational interventions designed to improve social support for teenagers.
\end{abstract}

Keywords: perceived social support; theoretical model; sources of social support; types of social support; adolescence; sustainable psychological development; family; friends and teachers; emotional; material and informational support; structural equations

\section{Introduction}

Although the initial studies on social support date from long before [1], the interest in this construct has increased exponentially since the 1970s [2], when, as a result of its association with well-being, it became a central focus for a large number of studies and interventions with the aim of improving the quality of life and psychosocial adjustment or enhancing people's well-being, which are goals of sustainable psychology [3].

The 1970s are therefore viewed as the true theoretical and empirical starting point of the study of social support [4], mainly thanks to works published by Cassel [5,6], Cobb [7] and Caplan [8], and the construct is now widely recognized by the scientific community as a key object of study [9], also within the psychology of sustainability [10], due to the close link between the support of the closest contexts and the quality of life and well-being of adolescents $[3,11]$. Hence the need to understand to what extent young people today feel supported by the principal sources in their immediate social environment. This in turn will help determine which aspects of social support require primary intervention in order to ensure the best possible level of school and personal adjustment [12] within the framework of the psychology of sustainability and sustainable development [13].

A historic overview of social support identifies it as a complex and dynamic metaconcept [14] with diverse dimensions and levels [15]. Nevertheless, due to the many different 
perspectives from which it can be viewed, the countless actions attributed to it and its dynamic nature [16,17], no consensus has yet been reached regarding its definition $[4,18,19]$. Moreover, its composition remains unclear, and there is as yet no general agreement about how it should be assessed [20].

This ambiguity notwithstanding, there are two seminal theories in the study of social support. The first is the one posited by Tardy [21], who conducted a theoretical review of social support measurement instruments in which he brought the ideas of many different authors together. The result of this pooling was a multidimensional, hierarchical theoretical model expressed as a vertical diagram comprising five interdependent dimensions distributed as follows (from top to bottom): direction (distinguishing between the support given and that received), disposition (available support vs. real support), description/evaluation (distinguishing between the support described and the satisfaction with the support received), content/type of support (emotional, instrumental, informational or appraisal) and network (family, friends, neighbors, colleagues, community, etc.).

The second theory is the one developed by Lin [22], who, almost in parallel with Tardy [21], carried out an exhaustive review of all the most relevant theoretical contributions made in connection with social support, with the aim of establishing a comprehensive, integrative definition that would encompass all of them. Lin posited a theoretical model with three areas or dimensions: (a) perceived support vs. real support; (b) sources of social support or areas in which it is provided, such as the community, social networks, trusted others; and (c) instrumental (e.g., someone driving you home) vs. expressive support (e.g., being able to vent with a close friend). As a result of this work, Lin [22,23] defined social support as the real or perceived instrumental and/or expressive support provided in everyday or crisis situations by the community, social networks or trusted partners. In the opinion of some authors, this is the definition which best reflects all the most characteristic aspects of other definitions [4,24].

It is evident that, despite clear discrepancies between the two models, they coincide in emphasizing the importance of taking different sources of support into account and distinguishing between the different types of support provided by these sources. They also both make it very clear that their proposals are mere examples, and that many alternative classifications are available in the current scientific literature, which may or may not be appropriate, depending on the specific context and participants [21,22]. Nevertheless, the principal limitation of both theories is the fact that, although many subsequent studies have attempted to examine the different sources and types of support, they have done so from a diverse range of approaches, without the necessary empirical foundation regarding what the main sources or key types of support should be [25-29].

Although total perceived support tends to be the most common variable analyzed, authors recommend distinguishing between different sources [30] in order to enable a more precise assessment of people's experience of social support [31]. Despite this, however, few studies have been conducted from this perspective [32], and the few found in relation to adolescence (the developmental period on which the present study focuses) can be classified into three groups. Firstly, there are those that focus only on family and peers [33-35]. What these studies fail to take into consideration is the fact that ecological theories [36] have identified the school context as a key environment, since teachers strongly influence children throughout their entire education [37]; nor indeed do they bear in mind the fact that more recent studies have highlighted family, peers and teachers as the three most important agents influencing adolescent students [38-41]. Secondly, there are those that focus on the support provided by teachers and peers, without taking the family into account [42]. And thirdly, there are those that analyze all three factors, but using complex or excessively long measurement instruments that cast doubt on the reliability of the results obtained [43-46].

The content or types of social support also vary greatly from study to study, since each author labels and classifies them differently [47]. Perhaps the best-known approach is that advocated by Lin [22], who generically grouped all proposals into two large-scale categories: 
instrumental support and expressive support. Nevertheless, although this approach is totally valid and widely accepted by the scientific community, the most popular one is currently that developed by Schaefer et al. [31,48], which distinguishes between emotional support (talking about personal problems, displays of encouragement, attachment, etc.), material support (direct material aid, care and favors, etc.), and informational support (helpful information, advice, feedback, etc.).

Although the scientific community has generally accepted the multidimensional nature of social support [49], its internal structure has yet to be reliably tested in order to confirm whether it is a hierarchical construct [21] or if each dimension is independent [22]. There are many reasons for this, including the fact that it is difficult to analyze a model which requires different measurement instruments or methods due to the dispersed nature of the proposed dimensions. Consequently, most studies have focused on examining the internal structure of the two lower dimensions of the construct (content/type of support and sources of support), but they have failed to report conclusive results or have concentrated solely on the individual analysis of each dimension. Moreover, none have adopted an approach which includes all three principal sources of support and all three of the most widely accepted types of support. Examples include: (a) the model developed by Vaux et al. [50], who tested five types of social support (emotional, socializing, practical assistance, financial assistance and advice/guidance) separately for family and friends; (b) the work by Dubow and Ullman [51], who analyzed, firstly, different types of support (tangible aid, emotional and informational support, and emotional support and boosting self-esteem), and, secondly, sources of support (peers, family and teachers); (c) the ninedimension model developed by Scholte et al. [29], which comprises different hierarchical levels located at the same level, five pertaining to different types of social support and the remaining four to sources of support; the solution is complex and even incoherent for the purposes of theoretical interpretation; and (d) studies such as that by Torsheim et al. [42] which, despite assessing different hierarchical levels or dimensions, such as sources and types of support, are only able to distinguish one of them, namely sources of support.

Despite their drawbacks, all these approaches seem to share a common denominator: the type of support derives from the source of said support [52-55], rather than the other way round, as Tardy [21] postulated in his original model.

Consequently, the principal aim of the present study is to test a theoretical model of perceived social support which is subdivided into two hierarchical dimensions (type of support and source of support), following the approach posited by Tardy [21], but also taking into consideration more recent empirical findings that have been widely accepted by the scientific community: (a) the three types of support are emotional, material and informational; (b) the main sources of support are family, friends and teachers; and (c) the source of support provides the type of support, which is why the source should be a higher hierarchical dimension. It is hypothesized that the hierarchical model that best fits the data will be the one in which the sources of support (family, friendships and teachers) correspond to a hierarchically higher level than the types of support (emotional, material and informational) (Figure 1).

Knowing the nature of perceived social support will make it possible to delve into a factor of educational and teaching style (support) that contributes to the development of socially adaptive behaviors in adolescents $[12,41,56,57]$ and, consequently, to the creation of a family and school environment that focuses on enhancing the well-being, quality of life and adjustment of these adolescents, so that they can achieve a sustainable psychological development $[3,11,13]$. 


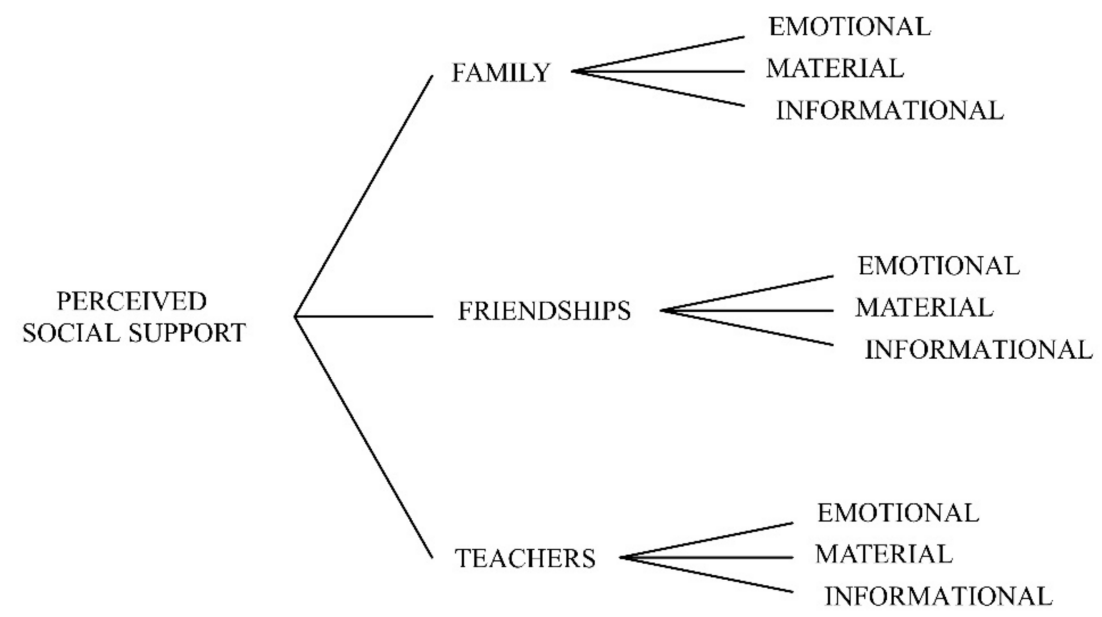

Figure 1. Hypothesized model.

\section{Materials and Methods}

\subsection{Participants}

A total of 1109 students participated in the study, although after eliminating those with extreme or inconsistent response patterns, the final sample comprised 1081. All participants were aged between 12 and 18 years $(\mathrm{M}=14.92$; $\mathrm{SD}=1.53)$ and were in compulsory secondary education. The sample was recruited from seven educational centers (three semi-private ones-650 participants, and four public ones-430 participants) in the north of Spain, with a medium socioeconomic level. In terms of gender, 48.9\% (529) were girls and 51.1\% (552) were boys. The sample was selected using systematic random sampling. Once all the centers had been selected by this procedure, the authors of the research contacted the management teams to confirm their participation. In the cases where the educational center refused to participate, another center was chosen using the same systematic random sampling, until the sample was complete.

\subsection{Measurement Instruments}

A single scale was used to measure perceived social support. Participants completed the APIK Perceived Social Support Questionnaire [58], which assesses three dimensions of perceived social support (support from family, support from friends and support from teachers) through 27 items rated on a 5-point Likert-type scale ( 1 = Totally disagree to 5 = Totally agree) (item examples include: "If I ask a favor, my family does it", "My friends are there whenever I need them", "My teachers are approachable"). Within each of the three dimensions, the items are grouped in accordance with the type of support (emotional, material or informational). The internal consistency value obtained by the scale with the sample used in the present study was Rho $=0.929$, which is considered excellent [59]. Reliability values were 0.974 for McDonald's Omega $(\Omega)$ and 0.585 for the average variance extracted for the full scale. In both cases, although particularly in the first one, the values exceeded the minimum requirements $[60,61]$. These values are also offered for each subscale—family: McDonald's Omega = 0.925, AVE = 0.583; friendships: McDonald's Omega $=0.917$, AVE $=0.559$; teachers: McDonald's Omega $=0.933$, AVE $=0.611$; family emotional: McDonald $=0.773, \mathrm{AVE}=0.534$; family material: McDonald $=0.748$, $\mathrm{AVE}=0.503$; family informational: $\mathrm{ccDonald}=0.881, \mathrm{AVE}=0.712$; friendships emotional: McDonald $=0.818$, AVE $=0.069$; friendships material: McDonald $=0.748$, AVE $=0.517$; friendships informational: McDonald $=0.783$, AVE $=0.552$; teachers emotional: McDonald $=0.794, \mathrm{AVE}=0.563$; teachers material: McDonald $=0.821, \mathrm{AVE}=0.617$; teachers informational: McDonald $=0.848, \mathrm{AVE}=0.652$. 


\subsection{Procedure}

After contacting the schools to request their participation in the study, meetings were held with the management teams to explain in detail the research aims and procedure. The authors went to those schools that agreed to participate to administer the questionnaires to those students who had handed in an informed consent form signed by their parents or legal guardians. The questionnaire was completed collectively during school hours (maximum $15 \mathrm{~min}$ ) in the participants' own classrooms. The instrument was administered by the authors of the present study, who resolved any doubts that arose during completion on an individual basis. In order to avoid a social desirability bias, students were not informed of the study aims and were assured that their answers would be anonymous and that their participation was completely voluntary.

The study was conducted in compliance with the Declaration of Helsinki and was approved by the University of the Basque Country's Ethics Committee for Research Relating to Humans (CEISH-UPV /EHU—M10_2018_261).

\subsection{Data Analysis}

Missing values $(0.17 \%)$ were replaced using the linear trend estimation at the point method. Following an analysis of outliers (extreme or inconsistent response patterns), 28 participants $(2.52 \%)$ were eliminated from the study. No participants were eliminated from the study for not responding to the minimum number of items. This preparatory phase of the data analysis was conducted using the SPSS v. 25 statistical software package [62].

Next, a confirmatory dimensional analysis was conducted based on a comparison of the empirical fit of the tested models, calculated using a combination of different goodness of fit indexes. This structural equations method was carried out using EQS v. 6.2 [63].

First, the fit of the data to a multivariate normal distribution was tested using Mardia's standardized coefficient. Given that the value obtained (93.78) far exceeded the maximum of five [63], the assumption of multivariate normality was rejected and the robust maximum likelihood estimation method was used, along with different goodness of fit indexes and the Satorra-Bentler correction for Chi-square [63,64].

To comply with the study's aim, three models were proposed, and the fit of each was calculated using different indicators. Given that the data deviated from normality and that, therefore, the use of Chi-square was not recommended [65], we used its normed version ( $\chi 2 / d f)[66]$, in this case with the Satorra-Bentler correction (SB $2 / \mathrm{df})$. Values of less than three are considered adequate [67]. Moreover, since it is best to use this statistic in combination with other goodness of fit indexes [68-70], the following incremental fit indexes were used [71]: CFI (Comparative Fit Index), NFI (Normed fit index), NNFI (NonNormed Fit Index) and IFI (Incremental Fit Index), for which values of 0.95 and over are considered indicative of adequate fit [72-74]. The RMSEA (Root Mean Square Error of Approximation) statistic was used as an absolute index of lack of fit [75], along with a 90\% confidence internal. Here, values lower than 0.05 indicate good fit [76,77], provided that the measurement instrument contains high standardized factor loadings, which can be tested by a reliability measure based on the magnitude of these factor loadings, such as McDonald's Omega [78]. This index is included in the scale description.

The parsimony fit indexes used were the AIC (Akaike Information Criterion) [79] and the CAIC (Consistent Version of AIC), which also takes sample size into account [80]. When evaluating the fit, these statistics indicate which of the models is the most parsimonious, with lower values being considered indicative of a better fit [63,81]. The AIC and CAIC parsimony fit statistics were also used in the comparison of the tested models.

\section{Results}

To test the internal structure of social support, three theoretical models were proposed and compared: (a) Model M1 (Figure 2), a hierarchical model with perceived social support at the first level, the orthogonal dimensions family support, support from friends and support from teachers at the second hierarchical level, and, within each source of support, 
another three orthogonal dimensions referring to emotional, material and informational support at the third hierarchical level. This is the hypothesized model in the present study. (b) Model M2 (Figure 3), which comprises general perceived social support at the first hierarchical level, from which three orthogonal dimensions derive at a second level, pertaining to type of support (emotional, material and informational), and, finally, at a third hierarchical level, another three orthogonal factors represent the different sources of support (family, friends and teachers) for each type of support. This model represents the directionality of the hierarchical levels proposed by Tardy [21]. (c) Model M3 (Figure 4), which represents Lin's [22] theory, according to which the types of support provided by the different sources would be independent situations [82] and would therefore correspond to a single-level construct model containing all the areas or dimensions proposed by Lin [22].

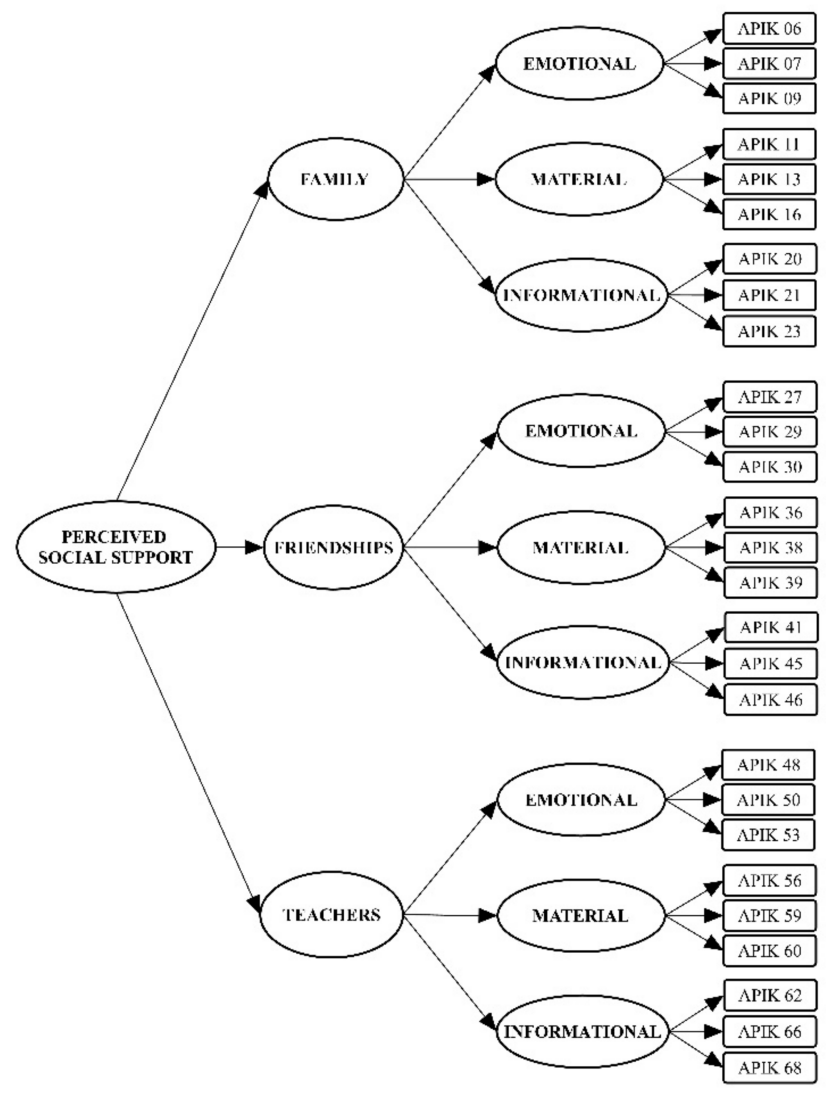

Figure 2. Model 1. 


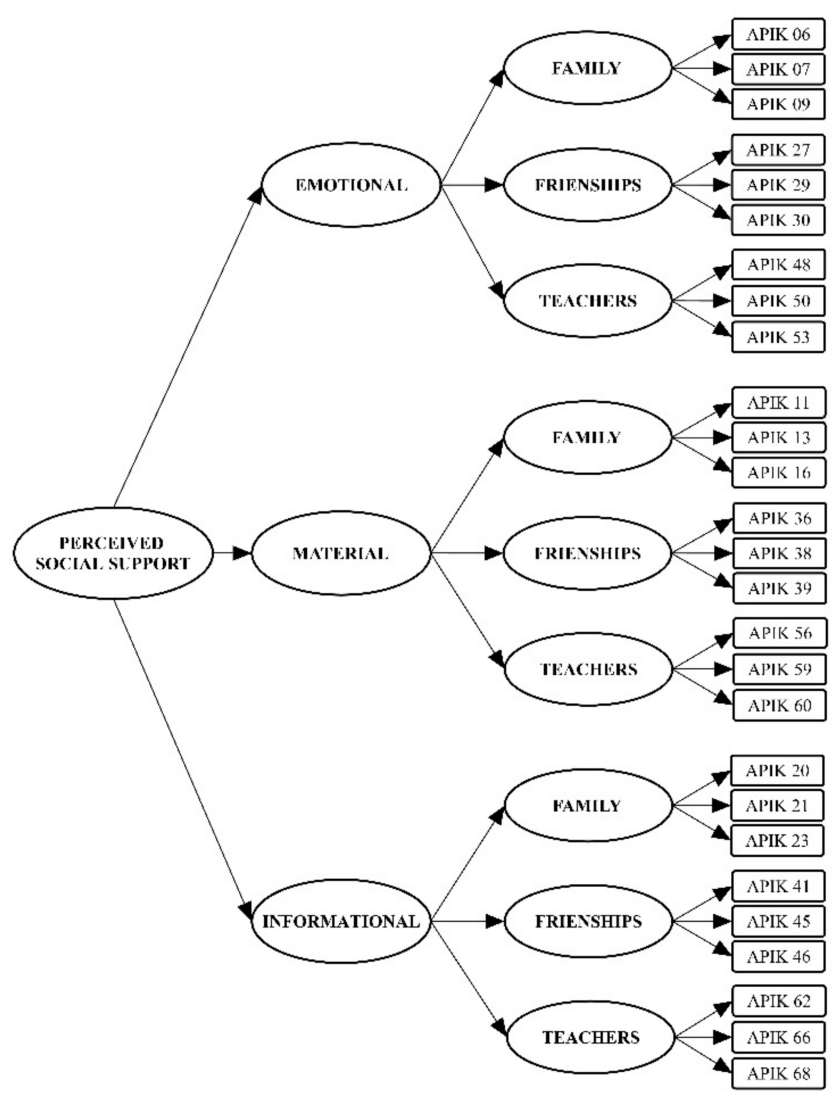

Figure 3. Model 2.

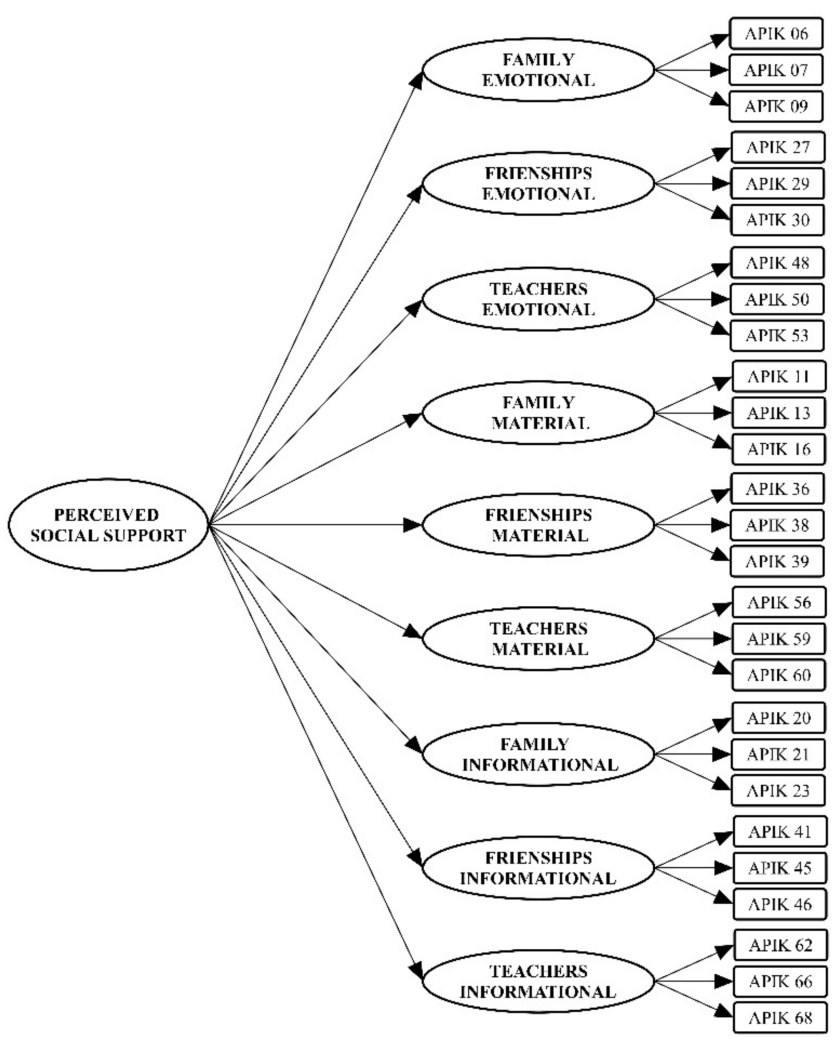

Figure 4. Model 3. 
Table 1 shows the different fit and parsimony indexes for each model.

Table 1. Parsimony and goodness of fit indexes for $M_{1}, M_{2}$ and $M_{3}$.

\begin{tabular}{cccc}
\hline & Model 1 & Model 2 & Model 3 \\
\hline \multicolumn{2}{c}{ Parsimony indexes } \\
AIC & 75.507 & 2332.576 & 2444.365 \\
CAIC & -1774.056 & 483.012 & 558.888 \\
& \multicolumn{2}{c}{ Fit indexes } \\
$\chi^{2}$ & 923.66 & 3954.00 & $13,718.954$ \\
SB $\chi^{2}(d f)$ & $693.50_{(309)}$ & $2950.57_{(309)}$ & $3074.3651_{(315)}$ \\
SB $\chi^{2} / d f$ & 2.24 & 9.54 & 9.75 \\
NFI & 0.949 & 0.785 & 0.776 \\
NNFI & 0.967 & 0.776 & 0.770 \\
IFI & 0.971 & 0.803 & 0.794 \\
CFI & 0.971 & 0.802 & 0.794 \\
RMSEA $_{(90 \% \text { CI })}$ & $0.034_{(0.031-0.037)}$ & $0.089_{(0.086-0.092)}$ & $0.090_{(0.087-0.093)}$ \\
\hline Note. $^{*} p<0.01 ; \mathrm{M}_{1}=$ Source-type model; $\mathrm{M}_{2}=$ Type-source model; $\mathrm{M}_{3}=$ Sources and types combined model.
\end{tabular}

As shown in Table 1, in several of the indexes calculated, the second (M2) and third model (M3) failed to attain the minimum values established as being indicative of acceptable fit. Specifically, the values obtained by these models in the NFI, NNFI, IFI and CFI indexes were 0.80 or lower, and the RMSEA value was above the cut-off of 0.080 , indicative of a minimum level of acceptable fit. Consequently, the results do not confirm the adequacy of these models. The first model (M1), however, returned very different results, with all values indicating an excellent fit of the data to the model. In the NNFI, IFI and CFI, the values obtained were over the 0.95 cut-off threshold, and only in the NFI was the value returned just on the limit (0.949). The RMSEA value was considerably lower than the limit indicating good fit (RMSEA < 0.05). The parsimony indexes (AIC and CAIC) also identified model M1 as having a better fit, since it obtained lower scores in both cases.

Thus, model M1, which posits a hierarchical model of perceived social support in which sources of support (family, friends and teachers) provide the type of support (emotional, material and informational), is the first-choice model for understanding the nature of social support.

\section{Discussion}

One of the central objectives of the psychology of sustainability is to reach an improvement in people's quality of life and well-being through the achievement of a good psychosocial adaptation [3]. For this purpose, taking into account the close connection between social support and quality of life or well-being [11,83], the support received from different contexts is essential, as it can make the difference between a sustainable development or the development and maintenance of pathologies and mental disorders. In the study of the role played by social support on adjustment, there is some controversy as to whether it is necessary to focus on the perceptions that people have about the support available (perceived support) or on the real and objective exchanges between the person and the context (received support) [16,84]. Although both types of support can make significant contributions to psychosocial adjustment [16], it seems that perception is more influential [84]. It is therefore interesting to delve into the nature and structure of the social support perceived by adolescents in their close contexts (family, friends and school) in order to learn how to enhance it and consequently facilitate the achievement of sustainable psychological development.

Hence, the aim of the present study was to verify a theoretical model of social support based on two theories which are considered benchmarks in the study of the construct. The first is the one developed by Tardy [21], which proposes a hierarchical, multidimensional organization of the construct, according to which the two most basic or lower levels pertain to type of support and (derived from that) support networks (family, friends, 
neighbors, colleagues, etc.). The second theory is that advanced by Lin [22], who posited a model with three areas or dimensions which, unlike Tardy's [21], are non-hierarchical and independent [82]: (a) perceived support vs. real support; (b) sources of support; and (c) type of support.

Moreover, the review of the extant literature in this field revealed that the sources of support that are most relevant to understanding the social support construct are family, peers and teachers [38-41]. In terms of the type of support, the review identified two main groups: instrumental or material, and expressive or emotional [22], to which informational support has recently been added [31], with this three-dimensional approach being the most widely supported one at present.

Bearing all these findings in mind, three possible theoretical models of perceived social support were compared. In two of the three cases, perceived social support is understood as a hierarchical, multidimensional construct, but while one of the models follows the hierarchical order proposed by Tardy [21], with types of support (emotional, material and informational) constituting the upper hierarchical level, and sources (family, friends and teachers) deriving from them, the other model hypothesized posited the reverse order, with sources of support comprising the higher hierarchical level and types of support deriving from them at a lower level. The third model would correspond to Lin's theory [22], and would propose a model of a single sublevel of constructs containing the combination of the different types of support provided by the different sources of support.

The results obtained by comparing the three models were unambiguous. The calculated goodness of fit indexes are well below the minimum levels required as acceptable in both the model derived from the traditional proposal of Tardy [21] (the sources of support derive from the type of support) and the model derived from Lin's theory [22]. In contrast, the other model tested (which reversed the order of Tardy [21] in the two hierarchical levels, positing that type of support derives from the source of that support) was found to fit the data well. While this contradicts Tardy's approach [21] regarding the hierarchical order of the two levels (first type of support and then sources of support), it is consistent with the findings of recent studies, which report solutions based on this new order [52-55].

Alongside the confirmation of this change in the theoretical approach, two other aspects are also worth highlighting. Firstly, the results confirm that, as proposed by previous studies [37-39], during adolescence, family, friends and teachers are all sources of support that should be taken into consideration when striving to understand how teenagers perceive their support network and what support it actually provides. Secondly, rather than just taking into account two types of support (material and emotional), as Lin [22] proposed in his original theory, the results confirm that informational support should also be considered [31]. This is consistent with the findings reported by those authors who advocate a three-dimensional approach to support [31,48] and is an important step forward in relation to the many studies which focus on adolescence but only analyze some of these sources, or do so independently [33-35,42]. It is also a step forward in relation to those studies which analyze diverse types of support using a wide range of different classification systems [28,29].

In the Social Sciences, and particularly in the field of Psychology, further research is required which combines and synthesizes the findings of previous research and is based on sound theoretical approaches. The diverse range of studies on a single topic that propose advances based on different (pseudo)theoretical proposals or theoretical approaches developed ad hoc, and which sometimes use similar yet not equivalent terminology, hamper the advance of knowledge, since they make it difficult (if not impossible) to compare findings and draw general conclusions about the issue at hand.

Consequently, the results obtained in the present study can be viewed as an important step forward in the study of the social support construct, since, up until now, the scientific community has widely accepted the multidimensional nature of the variable without sufficient, and sufficiently rigorous, evidence to support this view. Indeed, many studies 
have been carried out without a sufficiently solid theoretical grounding, which is perhaps why their results are often so different [25,27-29].

The confirmation of the theoretical model proposed here may provide a solid basis for future studies focused specifically on social support during adolescence, a developmental stage in which the support perceived by teenagers from those close to them is considered indispensable for a healthy development. Faced with constant changes and challenges, adolescents often need to perceive that they are receiving the social support they demand and need. Having a solid theoretical basis can be crucial for the development, within the framework of positive psychology, of primary interventions [85] aimed at achieving, explicitly, a better psychological and social adjustment from the promotion of this perceived support, and, implicitly, the psychology of sustainability $[86,87]$. To this must be added the relevance of having solid research that clarifies the nature and structure of perceived social support for the measurement and evaluation of the construct. Only in this way, on the basis of solid empirically tested theories, will the scientific community be able to develop valid instruments capable of rigorously measuring variables related to well-being and act in a preventive framework that focuses on improving the well-being and sustainable development of individuals [88], as well-being is one of the sustainable development objectives proposed by the United Nations [89].

Despite the advances achieved in the present study, it is important to remember two aspects: (a) perceived social support was assessed, which is a subjective measure of the received support that could not coincide with the real support; (b) Tardy's complete model [21] was not tested, only its two principal dimensions. Future studies may therefore wish to include other dimensions, such as evaluation or disposition. Not only would this enable greater insight into the hierarchical and multidimensional nature of the construct, it would also paint a clearer picture of how adolescents perceive the support they receive from their social network.

One of the limitations of the present study is that it focuses on one area of Spain. Future studies may therefore wish to include more heterogeneous samples from different areas of the country or even test the model with international samples as a means of enriching the data obtained.

Author Contributions: Conceptualization, I.I.-d.-1.-F. and A.R.-F.; methodology, I.I.-d.-1.-F., A.R.-F. and L.A.; formal analysis, I.I.-d.-1.-F. and A.R.-F.; resources, I.I.-d.-1.-F., N.E. and L.A.; data curation, I.I.-d.-l.-F., A.R.-F. and N.E.; writing-original draft preparation, I.I.-d.-1.-F.; writing-review and editing, I.I.-d.-1.-F., A.R.-F., N.E. and L.A.; visualization, I.I.-d.-l.-F., L.A., A.R.-F. and N.E.; supervision, A.R.-F.; project administration, A.R.-F.; funding acquisition, A.R.-F. All authors have read and agreed to the published version of the manuscript.

Funding: This research was funded by the consolidated research group IT1217-19 of the Basque University System and of the project EDU2017-83949-P of the State Subprogram of Knowledge Generation of the Ministry of Economy, Industry and Competitiveness of Spain. Its second author is beneficiary of the Pre-doctoral Training Programme for Non-Doctoral Research Staff of the Basque Government's Department of Education.

Institutional Review Board Statement: The study was conducted according to the guidelines of the Declaration of Helsinki, and approved by Ethics Committee of University of the Basque Country (protocol code M10_2018_261, 24 January 2019).

Informed Consent Statement: Informed consent was obtained from all subjects involved in the study.

Data Availability Statement: The data presented in this study are available on request from the corresponding author. The data are not publicly available due to containing information that could compromise the research participants' privacy/consent.

Conflicts of Interest: The authors declare no conflict of interest. The funders had no role in the design of the study; in the collection, analyses, or interpretation of data; in the writing of the manuscript, or in the decision to publish the results. 


\section{References}

1. Landeta, O.; Breva, A. Evolución histórica en el estudio del apoyo social. Rev. Hist. Psicol. 2000, 21, 589-596.

2. Cohen, S.; Syme, S.L. Issues in the study and application of social support. In Social Support and Health; Cohen, S., Syme, S.L., Eds.; Academic Press: San Diego, CA, USA, 1985; pp. 3-22.

3. Bagán, G.; Tur-Porcar, A.M.; Llorca, A. Learning and Parenting in Spanish Environments: Prosocial Behavior, Aggression, and Self-Concept. Sustainability 2019, 11, 5193. [CrossRef]

4. Gracia, E. El Apoyo Social En La Intervención Comunitaria; Paidós Ibérica: Barcelona, Spain, 1997.

5. Cassel, J.C. Psychiatric epidemiology. In Americans Handbook of Psychiatry; Caplan, G., Ed.; Basic Books: New York, NY, USA, 1974; pp. 401-410.

6. Cassel, J.C. Psychosocial processes and 'stress': Theoretical formulation. Int. J. Health Serv. 1974, 4, 471-482. [CrossRef] [PubMed]

7. Cobb, S. Social support as a moderator of life stress. Psychosom. Med. 1976, 38, 300-314. [CrossRef]

8. Caplan, G. Support Systems and Community Mental Health: Lectures on Concept Development; Behavioral Publications: Pasadena, CA, USA, 1974

9. Gracia, E.; Herrero, J.; Musitu, G. El Apoyo Social; PPU: Barcelona, Spain, 1995.

10. Bae, S.Y.; Chang, P.-J.; Lee, C.-K. Structural relationships among online community use, parental stress, social support, and quality of life between korean and taiwanese employed mothers. Sustainability 2020, 12, 10681. [CrossRef]

11. Bellini, D.; Crescentini, A.; Zanolla, G.; Cubico, S.; Favretto, G.; Faccincani, L.; Ardolino, P.; Gianesini, G. Mathematical Competence Scale (MCS) for primary school: The psychometric properties and the validation of an instrument to enhance the sustainability of talents development through the numeracy skills assessment. Sustainability 2019, 11, 2569. [CrossRef]

12. Rodríguez-Fernández, A.; Ramos-Díaz, E.; Fernández-Zabala, A.; Goñi, E.; Esnaola, I.; Goñi, A. Contextual and psychological variables in a descriptive model of subjective well-being and school engagement. Int. J. Clin. Health Psychol. 2016, 16, 166-174. [CrossRef]

13. Di Fabio, A.; Saklofske, D.H. The contributions of personality traits and emotional intelligence to intrapreneurial self-capital: Key resources for sustainability and sustainable development. Sustainability 2019, 11, 1240. [CrossRef]

14. Wilcox, B.L.; Vernberg, E.M. Conceptual and theoretical dilemmas facing social support research. In Social Support: Theory, Research and Applications; Sarason, I.G., Sarason, B.R., Eds.; Springer: Dordrecht, The Netherlands, 1985; pp. 3-20. [CrossRef]

15. Barrón, A.; Sánchez, E. Estructura social, apoyo social y salud mental. Psicothema 2001, 13, 17-23.

16. Barrón, A. Apoyo Social: Aspectos Teóricos y Aplicaciones; Siglo XXI: Madrid, Spain, 1996.

17. Varela, I. Apoyo Social y Afrontamiento En Enfermedad Cardíaca. Ph.D. Thesis, Complutense University of Madrid, Madrid, Spain, 2011.

18. Veiel, H.; Baumann, U. Comments on concepts and methods. In The Meaning and Measurement of Social Support; Veiel, H., Baumann, U., Eds.; Hemisphere: New York, NY, USA, 1992; pp. 313-319.

19. Domínguez, J.M. Apoyo Social, Integración y Calidad de Vida de La Mujer Inmigrante. Ph.D. Thesis, Malaga University, Málaga, Spain, 2006.

20. Sarason, I.G.; Sarason, B.R. Social support: Mapping the construct. J. Soc. Pers. Relat. 2009, 26, 113-120. [CrossRef]

21. Tardy, C.H. Social support measurement. Am. J. Community Psychol. 1985, 13, 187-202. [CrossRef]

22. Lin, N. Conceptualizing social support. In Social Support, Life Events and Depression; Lin, N., Dean, A., Ensel, W., Eds.; Academic Press: New York, NY, USA, 1986; pp. 17-30. [CrossRef]

23. Lin, N.; Ensel, W.M. Life stress and health: Stressors and resources. Am. Sociol. Rev. 1989, 54, 382-399. [CrossRef]

24. Azpiazu, L.; Esnaola, I.; Sarasa, M. Capacidad predictiva del apoyo social en la inteligencia emocional de adolescentes. Eur. J. Educ. Psychol. 2015, 8, 23-29. [CrossRef]

25. Joseph, S.; Andrews, B.; Williams, R.; Yule, W. Crisis support and psychiatric symptomatology in adult survivors of the Jupiter cruise ship disaster. Br. J. Clin. Psychol. 1992, 31, 63-73. [CrossRef]

26. Newcomb, M.D.; Bentler, P.M. Loneliness and social support: A confirmatory hierarchical analysis. Personal. Soc. Psychol. Bull. 1986, 12, 520-535. [CrossRef]

27. Power, M.J.; Champion, L.A.; Aris, S.J. The development of a measure of social support: The Significant Others (SOS) Scale. Br. J. Clin. Psychol. 1988, 27, 349-358. [CrossRef] [PubMed]

28. Richman, J.M.; Rosenfeld, L.B.; Hardy, C.J. The social support survey: A validation study of a clinical measure of the social support process. Res. Soc. Work Pract. 1993, 3, 288-311. [CrossRef]

29. Scholte, R.H.J.; van Lieshout, C.F.M.; van Aken, M.A.G. Perceived relational support in adolescence: Dimensions, configurations, and adolescent adjustment. J. Res. Adolesc. 2001, 11, 71-94. [CrossRef]

30. Mendoza, M.I.; Carrasco, A.M.; Mendoza, R. Bienestar percibido y percepción del apoyo parental y de los amigos en los adolescentes españoles. In Intervención Psicosocial y Psicología Comunitaria; Fernández del Valle, J., Herrero, J., Bravo, A., Eds.; Biblioteca Nueva: Madrid, Spain, 2000; pp. 105-111.

31. Hombrados, I.; Castro, M. Apoyo social, clima social y percepción de conflictos en un contexto educativo intercultural. An. Psicol. 2013, 29, 108-122. [CrossRef]

32. Thompson, R.A.; Flood, M.F.; Goodvin, R. Social support and developmental psychopathology. In Developmental Psychopathology: Risk, Disorder, and Adaptation; Cicchetti, D., Cohen, D.J., Eds.; John Wiley \& Sons: Hoboken, NJ, USA, 2006; pp. 1-37.

33. Calvo, F.; Alemán, I. Validación del Cuestionario de Apoyo Social (CAS): Estudio preliminar. Ansiedad Estrés 2006, 12, 63-74. 
34. González, M.T.; Landero, R. Propiedades psicométricas de la Escala de Apoyo Social Familiar y de Amigos (AFA-R) en una muestra de estudiantes. Acta Investig. Psicol.ógica 2014, 4, 1469-1480. [CrossRef]

35. Hardesty, P.H.; Richardson, G.B. The structure and validity of the Multidimensional Social Support Questionnaire. Meas. Eval. Couns. Dev. 2012, 45, 181-196. [CrossRef]

36. Bronfenbrenner, U. Making Human Beings Human: Bioecological Perspectives on Human Development; Sage Publications: Thousand Oaks, CA, USA, 2005.

37. Eccles, J.S.; Roeser, R.W. Schools as developmental contexts. In Blackwell Handbook of Adolescence; Adams, G., Berzonsky, M.D., Eds.; Blackwell Publishing: Malden, MA, USA, 2003; pp. 129-148.

38. Piko, B.F.; Hamvai, C. Parent, school and peer-related correlates of adolescents' life satisfaction. Child. Youth Serv. Rev. 2010, 32, 1479-1482. [CrossRef]

39. Wentzel, K.; Russell, S.; Baker, S. Emotional support and expectations from parents, teachers, and peers predict adolescent competence at school. J. Educ. Psychol. 2016, 108, 242-255. [CrossRef]

40. Ramos-Díaz, E.; Rodríguez-Fernández, A.; Fernández-Zabala, A.; Revuelta, L.; Zuazagoitia, A. Apoyo social percibido, autoconcepto e implicación escolar de estudiantes adolescentes. Rev. Psicodidáctica 2016, 21, 339-356. [CrossRef]

41. Fernández-Lasarte, O.; Ramos-Díaz, E.; Goñi, E.; Rodríguez-Fernández, A. The role of social support in school adjustment during secondary education. Psicothema 2020, 32, 100-107. [CrossRef]

42. Torsheim, T.; Wold, B.; Samdal, O. The Teacher and Classmate Support Scale: Factor structure, test-retest reliability and validity in samples of 13- and 15-year-old adolescents. Sch. Psychol. Int. 2000, 21, 195-212. [CrossRef]

43. Hombrados, M.I.; Gomez, L.; Dominguez, J.M.; Garcia, P.; Castro, M. Types of social support provided by parents, teachers, and classmates during adolescence. J. Community Psychol. 2012, 40, 645-664. [CrossRef]

44. Malecki, C.; Demaray, M. Measuring perceived social support: Development of the Child and Adolescent Social Support Scale. Psychol. Sch. 2001, 39, 1-18. [CrossRef]

45. Mestre, M.V.; Frías, M.D.; García-Ros, R.; Moreno, C. Análisis psicométrico y factorial de la escala de apoyo social (familiar, escolar y social) para adolescentes. Psicol. Rev. Metodol. Psicol. Exp. 1993, 14, 193-208.

46. Nolten, P.W. Conceptualization and Measurement of Social Support: The Development of the Student Social Support Scale. Ph.D. Thesis, University of Wisconsin-Madison, Madison, WI, USA, 1994.

47. Vaux, A. Assessment and analysis. In The Meaning and Measurement of Social Support; Veiel, H., Baumann, U., Eds.; Hemisphere: New York, NY, USA, 1992; pp. 193-216.

48. Schaefer, C.; Coyne, J.C.; Lazarus, R.S. The health-related functions of social support. J. Behav. Med. 1981, 4, 381-406. [CrossRef]

49. Yin, M.; Tayyab, S.M.; Xu, X.-Y.; Jia, S.-W.; Wu, C.-L. The investigation of mobile health stickiness: The role of social support in a sustainable health approach. Sustainability 2021, 13, 1693. [CrossRef]

50. Vaux, A.; Riedel, S.; Stewart, D. Modes of social support: The Social Support Behaviors (SS-B) scale. Am. J. Community Psychol. 1987, 15, 209-232. [CrossRef]

51. Dubow, E.F.; Ullman, D.G. Assessing social support in elementary school children: The Survey of Children's Social Support. J. Clin. Child Psychol. 1989, 18, 52-64. [CrossRef]

52. García-Martín, M.A.; Hombrados, I.; Gómez, L.A. Multidimensional approach to social support: The Questionnaire on the Frequency of and Satisfaction with Social Support (QFSSS). An. Psicol. 2016, 32, 501. [CrossRef]

53. Gordon-Hollingsworth, A.T.; Thompson, J.E.; Geary, M.A.; Schexnaildre, M.A.; Lai, B.S.; Kelley, M.L. Social Support Questionnaire for Children: Development and initial validation. Meas. Eval. Couns. Dev. 2015, 49, 122-144. [CrossRef]

54. Landeta, Ó.; Calvete, E. Adaptación y validación de la Escala Multidimensional de Apoyo Social Percibido. Ansiedad Estrés 2002, 8, 173-182.

55. Pastor, Y.; Quiles, Y.; Pamies, L. Social support in adolescence: Adaptation and psychometric properties of the Social Support Scale for Children by Harter (1985). Int. J. Soc. Psychol. 2012, 27, 39-53. [CrossRef]

56. Nagy-Pénzes, G.; Vincze, F.; Bíró, É. Contributing factors in adolescents' mental well-being-The role of socioeconomic status, social support, and health behavior. Sustainability 2020, 12, 9597. [CrossRef]

57. Lee, G.; Park, T.I.; Cho, H. Maladaptive perfectionism and college adjustment of international students in Korea: A moderated mediation model of social support. Sustainability 2020, 12, 4729. [CrossRef]

58. Izar-de-la-Fuente, I.; Rodríguez-Fernández, A.; Escalante, N. Medida del apoyo social percibido (APIK) en la adolescencia. Eur. J. Investig. Health Psychol. Educ. 2019, 9, 83-94. [CrossRef]

59. Chin, W.W. The partial least squares approach for structural equation modeling. In Modern Methods for Business Research; Marcoulides, G.A., Ed.; Lawrence Erlbaum Associates Publishers: Mahwah, NJ, USA, 1998; pp. 295-336.

60. Nunnally, J.C. Psychometric Theory; McGraw-Hill Series in Psychology: New York, NY, USA, 1967.

61. Hair, J.F.; Black, W.C.; Babin, B.J.; Anderson, R.E. Multivariate Data Analysis, 7th ed.; Pearson: Edinburgh Gate, UK, 2014.

62. IBM Corporation. IBM SPSS Statistics for Windows; Version 25.0; IBM Corp: Armonk, NY, USA, 2017.

63. Bentler, P.M. EQS Structural Equations Program Manual; Multivariate Software: Encino, CA, USA, 2006.

64. Satorra, A.; Bentler, P.M. A scaled difference chi-square test statistic for moment structure analysis. Psychometrika 2001, 66, 507-514. [CrossRef]

65. McIntosh, C.N. Rethinking fit assessment in structural equation modelling: A commentary and elaboration on Barrett (2007). Pers. Individ. Dif. 2007, 42, 859-867. [CrossRef] 
66. Wheaton, B.; Muthén, B.; Alwin, D.F.; Summers, G. Assessing reliability and stability in panel models. Sociol. Methodol. 1977, 8, 84-136. [CrossRef]

67. Byrne, B.M. Multivariate Applications Book Series. Structural Equation Modeling with AMOS: Basic Concepts, Applications, and Programming; Lawrence Erlbaum Associates: Mahwah, NJ, USA, 2001.

68. Carretero-Dios, H.; Pérez, C. Normas para el desarrollo y revisión de estudios instrumentales. Int. J. Clin. Health Psychol. 2005, 5 , 521-551.

69. Bentler, P.M. On tests and indices for evaluating structural models. Pers. Individ. Dif. 2007, 42, 825-829. [CrossRef]

70. Miles, J.; Shevlin, M. A time and a place for incremental fit indices. Pers. Individ. Dif. 2007, 42, 869-874. [CrossRef]

71. Hu, L.; Bentler, P.M. Cutoff criteria for fit indexes in covariance structure analysis: Conventional criteria versus new alternatives. Struct. Equ. Model. 1999, 6, 1-55. [CrossRef]

72. Schumacker, R.E.; Lomax, R.G. A Beginner's Guide to Structural Equation Modeling, 2nd ed.; Lawrence Erlbaum Associates: Mahwah, NY, USA, 2010.

73. Kline, R.B. Principles and Practice of Structural Equation Modeling, 4th ed.; Guilford Press: New York, NY, USA, 2016.

74. Bentler, P.M.; Bonett, D.G. Significance tests and goodness of fit in the analysis of covariance structures. Psychol. Bull. 1980, 88, 588-606. [CrossRef]

75. Browne, M.W.; MacCallum, R.C.; Kim, C.-T.; Andersen, B.L.; Glaser, R. When fit indices and residuals are incompatible. Psychol. Methods 2002, 7, 403-421. [CrossRef]

76. Browne, M.W.; Cudeck, R. Alternative ways of assessing model fit. In Testing Structural Equation Models; Bollen, K.A., Long, J.S., Eds.; Sage: Newbury Park, CA, USA, 1992; pp. 136-162. [CrossRef]

77. Marsh, H.W.; Hau, K.-T.; Wen, Z. In search of golden rules: Comment on hypothesis-testing approaches to setting cutoff values for fit indexes and dangers in overgeneralizing Hu and Bentler's (1999) findings. Struct. Equ. Model. 2004, 11, 320-341. [CrossRef]

78. McNeish, D.; An, J.; Hancock, G.R. The thorny relation between measurement quality and fit index cutoffs in latent variable models. J. Pers. Assess. 2018, 100, 43-52. [CrossRef]

79. Akaike, H. Factor analysis and AIC. Psychometrika 1987, 52, 317-332. [CrossRef]

80. Bozdogan, H. Model selection and Akaike's Information Criterion (AIC): The general theory and its analytical extensions. Psychometrika 1987, 52, 345-370. [CrossRef]

81. Tomás, J.M.; Oliver, A. Efectos de formato de respuesta y método de estimación en análisis factorial confirmatorio. Psicothema 1998, 10, 197-208.

82. Herrero, J. Introducción a la psicología comunitaria. In Introducción a la Psicología Comunitaria; Musitu, G., Herrero, J., Cantera, L., Montenegro, M., Eds.; UOC: Barcelona, Spain, 2004; pp. 116-140.

83. Huang, Y.-H.; Sung, C.-Y.; Chen, W.T.; Liu, S.-S. Relationships between social support, social status perception, social identity, work stress, and safety behavior of construction site management personnel. Sustainability 2021, 13, 3184. [CrossRef]

84. Vaux, A. An ecological approach to understanding and facilitating social support. J. Soc. Pers. Relat. 1990, 7, 507-518. [CrossRef]

85. Seligman, M.E.; Csikszentmihalyi, M. Positive psychology. An introduction. Am. Psychol. 2000, 55, 5-14. [CrossRef]

86. Di Fabio, A. Positive Healthy Organizations: Promoting well-being, meaningfulness, and sustainability in organizations. Front. Psychol. 2017, 8, 1938. [CrossRef]

87. Di Fabio, A. The Psychology of sustainability and sustainable development for well-being in organizations. Front. Psychol. 2017, 8, 1534. [CrossRef]

88. Bee Seok, C.; Abd Hamid, H.S.; Mutang, J.A.; Ismail, R. Psychometric properties of the State-Trait Anxiety Inventory (Form Y) among Malaysian university students. Sustainability 2018, 10, 3311. [CrossRef]

89. United Nations. Sustainable Development Goals: 17 Goals to Transform Our World. 2015. Available online: http://www.un.org/ sustainabledevelopment/development-agenda/ (accessed on 5 February 2021). 